\title{
Group Farmers Association and the Success of Rural Agribusiness Development Program
}

\author{
Achmad Faqih*, Siti Aisyah \\ Department of Agribusiness, Faculty of Agriculture \\ University of Swadaya Gunung Jati \\ Cirebon, Indonesia \\ *afaqih024@gmail.com
}

\author{
Roosganda Elizabeth \\ Pusat Sosial Ekonomi dan Kebijakan Pertanian \\ Jln. Tentara Pelajar No.3B Cimanggu \\ Bogor, Indonesia
}

\begin{abstract}
Leadership function affects the performance that exists in an organization and is expected to bring changes in organizational life. The objectives of the current studies were to find out: (1) the relationship between Group Farmers Association (Gapoktan) leadership function partially with the success of the Rural Agribusiness Development Program (PUAP), (2) the relationship of Gapoktan leadership function simultaneously with the success of the PUAP program. The authors conducted the research in Gapoktan Tani Makmur located in a small Village, in Indonesia in March to July 2018. A quantitative method with descriptive survey was taken from primary and secondary data. Primary data were obtained from interview and questionnaire with some farmer groups to determine the Gapoktan function in terms of the success of the PUAP program. The study conducted some literature study to get secondary data, various agencies as well as related institutions. The results showed that: (1) There was significant relationship between Gapoktan leadership function partially with the level of success of the rural agribusiness development program (PUAP). That the better the functions of Gapoktan leader, the higher level of success of the program. (2) There was significant relationship between leadership function simultaneously with the success of PUAP program in the Village, obtained $r s=0.654$ and the tcount of 6.754, this has a strong relationship level. That the better the Gapoktan leadership function the higher level of success of the PUAP program.
\end{abstract}

Keywords: Group Farmer Association, agribusiness development program

\section{INTRODUCTION}

Agricultural Development is a process aimed at improving agricultural products as well as increasing income and productivity through the development in capital, skills, and natural resources. Agricultural is one of best sectors which contribute in the economic development in Indonesia as stated in [1]. Targets to accomplish within the sector are the growth on national food security through an independency stand in agricultural commodities yet, less dependent in food import, the improvements of not only value-added and competitiveness in agricultural commodities but also utilization of sustainable natural resources. Agricultural sector is also the main key to reach national food security, moderate poverty, and job recruitment.
National Agricultural Development is still not able to raise the degree of the subject of agriculture (farmers) in the broadest sense, because it is still in traditional or conventional even tends to decrease as described [2]. Poverty in rural areas is a major national problem whose countermeasures cannot be postponed and must be a top priority in the implementation of social welfare development [3]. Therefore, national and agricultural-based national economic development will directly or indirectly have an impact on reducing the poor population.

Rural Agribusiness Development Plan (PUAP) is one of the programs developed by the Department of Agriculture which is integrated with the National Community Empowerment Program (PNPM-M). Rural Agribusiness Development is a facilitation of venture capital assistance from for farmers, both farm owners, sharecroppers, farm labourers and farm households, coordinated by the Association of Group Farmers (Gapoktan). Gapoktan is an institutional for farmers implementing the PUAP and distributing venture capital assistance to all members. To achieve the goal on PUAP, Gapoktan is accompanied by PUAP Assistant Staff (Extension and Supervisors of Farmers) [4] to accelerate the growth and development of agribusiness with the goal of reducing poverty and unemployment in rural areas. The conquest in the number of low financial farmers is one indicator of the success in PUAP program. Its success or failure is determined by factors influencing the program. One of those is Gapoktan leadership function.

Leadership is the ability that a person has in order to influence others to work towards their goals and objectives [5] The ability will determine the ways used by the members to achieve work in an organization. This is also due to the presence of good and professional leaders who can influence the performance of its members [6]

Leaders today are required to have quality knowledge and able to understand various issues that concern the interests of the people they lead [7]. In addition, good cooperation will be established between leader and his/her men. In order to achieve the situation, a leader is expected to have an excellent personal skill of communication to maintain his/her functions of leadership. The functions will bridge working environment and is hoped to bring some changes in an organization [8]. 
The functions of leadership are undoubtfully necessary in the social interaction among the groups or organization [9]. There are five main functions of the leadership [10]: Functions of instruction, consultation, participation, delegation and control function. In order to improve agricultural development in Mayung Village, Gunung Jati Sub district, Cirebon Regency, one of which is the availability of capital and the need for agricultural production facilities for farmers to fulfilled. The Association of Group Farmers (GAPOKTAN) was officially established Gapoktan Tani Makmur as a forum among farmers both in the crop sector, horticulture and animal husbandry.

The problem that often occurs in the village is, the lack of attention among members on the instructions given by the leader. His/her little knowledge of leadership can certainly affect the overall success in PUAP program.

\section{METHODS}

The researchers carried out the study in Mayung Village, Gunung Jati Sub district in March to July 2018. Object of the research was the Association of Group Farmers (Gapoktan) Tani Makmur with 66 farmers as the respondent. Descriptive quantitative research design was chosen with the objective was to explain characteristics of a group people, estimate unit of percentage in a population which shows specific behaviour, to find out characteristics of product, to examine the relationship between variables and to search specific prediction [11].

Data involved in the current study were primary and secondary data. The study used informal interview with some related institutions and literary reviews on some documents. The study performed a descriptive survey through interview, questionnaire, observation and documentation as technique of data collection. The authors then analysed data by implementing validity and reliability tests in Likert Scale. To determine the relationship between functions of leadership and the successful of PUAP program, Spearman Rank Correlation analysis was applied [12]

\section{RESUltS AND DisCUSSION}

\section{A. Instructional Functions and the Success of PUAP}

To determine the relationship between the instructional function and the success of the Rural Agribusiness Development Program, Spearman Rank correlation analysis was used. The results of the correlation analysis turned out to have a real significant relationship between instructional function of the leader (X1-variable) and the success of the PUAP program (Y-variable).

Detail of the results of the statistical calculation of the correlation is as follows:

TABLE I. THE CORRELATION BETWEEN INSTRUCTIONAL FUNCTIONS AND THE SUCCESS OF PUAP PROGRAM

\begin{tabular}{|l|l|l|}
\hline \multicolumn{1}{|c|}{ No } & \multicolumn{1}{|c|}{ Components } & \multicolumn{1}{c|}{ Values } \\
\hline 1. & Coefficient Correlation $(\mathrm{r})$ & 0,427 \\
\hline 2. & Significant Difference & Moderate \\
\hline 3. & $\mathrm{t}_{\text {count }}$ & 3,688 \\
\hline
\end{tabular}

Table I. Cont.

\begin{tabular}{|l|l|l|}
\hline No & \multicolumn{1}{|c|}{ Components } & \multicolumn{1}{c|}{ Values } \\
\hline 4. & $\left(\mathrm{t}_{0,05(63-2)}\right.$ & 1,671 \\
\hline 5. & Significance & Real \\
\hline \multicolumn{2}{|c|}{ Source: Results of data analysis (2018) }
\end{tabular}

Based on statistical calculation using Spearman Rank Correlation, the $r$ value shown on the table is 0.427 . This means, the correlation between the functions of instruction and the successful of PUAP program is categorized as moderate. Meanwhile, based on the significant t-test, value of $t_{\text {count }}$ is of 3.688. It is higher than 1.671 with degree of freedom of $5 \%$. This shows that the relationship of the instructional functions of a leader towards the successful of PUAP program is significantly different.

According to the results on this study, it turns out that the instructional functions of a leader in the success of the Rural Agribusiness Development Program (PUAP) have a real significant relationship. Therefore, the instruction can be carried out by their members to make RDKK or Definitive Plans for Group Needs.

The instructional function is a form of one-way communication. The leader as a communicator is the agent that determines what, how, when and where the order is effectively implemented and carries out effective decisions [13]. Effective leadership requires the ability to move and motivate others to carry out orders [14].

\section{B. Consulting Functions and the Success of PUAP}

To define the relationship between the instructional function and the success of the Rural Agribusiness Development Program, Spearman Rank correlation analysis was used. The results of the correlation analysis turned out to have a real significant relationship between consulting function of the leader (X2-variable) and the success of the PUAP program (Y-variable). The results are as follows:

TABLE II. THE CORRELATION BETWEEN CONSULTING FUNCTIONS AND THE SUCCESS OF PUAP PROGRAM

\begin{tabular}{|l|l|l|}
\hline No & \multicolumn{1}{|c|}{ Components } & \multicolumn{1}{|c|}{ Values } \\
\hline 1. & Coefficient Correlation $(\mathrm{r})$ & 0,422 \\
\hline 2. & Significant Difference & Moderate \\
\hline 3. & $\mathrm{t}_{\text {count }}$ & 3,635 \\
\hline 4. & $\left(\mathrm{t}_{0,05(63-2)}\right.$ & 1,671 \\
\hline 5. & Significance & Real \\
\hline
\end{tabular}

Source: Results of data analysis (2018)

Based on statistical calculation using Spearman Rank Correlation, the $r$ value shown on the table is 0.422 . This means that the correlation between consulting functions and the successful of PUAP program is categorized as moderate. Meanwhile, based on the significant t-test, value of $t_{\text {count }}$ is of 3.635. It is higher than 1.671 with degree of freedom of $5 \%$. This shows that the relationship of consulting functions of a leader towards the successful of PUAP program is significantly different.

In accordance with the results on statistical calculation above, function of the leader in consulting and the success of 
the program has a significant relationship. The role of a leader in accordance with the ability in giving opportunities to all members in the group to have discussion session leads the authority to be a good listener to the problems faced by the members in the group instead of tends to be listened. This boosts an interactive and communicative milieu in developing leadership, as well as shares and informs savings and loans for all PUAP membership [15].

\section{Participatory Functions and the Success of PUAP}

To find out the relationship between the function and its success in PUAP, the study conducted a statistical calculation using Spearman Rank correlation analysis. The results of the correlation analysis applied showed a real significant correlation between participatory function (X3-variable) and the success of the PUAP program (Y-variable). The results are shown in the following table.

TABLE III. THE CORRELATION BETWEEN PARTICIPATORY FUNCTIONS AND THE SUCCESS OF PUAP PROGRAM

\begin{tabular}{|l|l|l|}
\hline No & \multicolumn{1}{|c|}{ Components } & \multicolumn{1}{c|}{ Values } \\
\hline 1. & Coefficient Correlation $(\mathrm{r})$ & 0,422 \\
\hline 2. & Significant Difference & Moderate \\
\hline 3. & $\mathrm{t}_{\text {count }}$ & 3,635 \\
\hline 4. & $\left(\mathrm{t}_{0,05(63-2)}\right.$ & 1,671 \\
\hline 5. & Significance & Real \\
\hline \multicolumn{2}{|c|}{ Source: Results of data analysis (2018) }
\end{tabular}

As shown in the table above, results on statistical Spearman Rank on $r$ value is 0.422 . This presents that the relationship between participatory function of a leader (X3-variable) and PUAP program (Y-variable) is moderate. On the other hand, based on the t-test calculation, value of $t_{\text {count }}$ is of 3.635. It is higher than 1.671 with degree of freedom of $5 \%$. This demonstrates a significant different between the relationship of the functions and the successful of PUAP program. The results prove that the more the leader participates in the program, the higher the results and the achievement will be. The participation could be realized in terms of planning and evaluating with all group members just before growing season. The leader evaluates the annual planning, implementation, and final data activities in the form of notebook for the future plans [16].

\section{Delegate Functions and the Success of PUAP}

The study applied Spearman Rank Coefficient analysis to test the variables. Results on the following table show that there is a significant correlation between Delegate Functions (X4-variable) and PUAP program (Y-variable)

TABLE IV. THE CORRELATION BETWEEN DELEGATE FunCTION AND THE SUCCESS OF PUAP

\begin{tabular}{|l|l|l|}
\hline No & \multicolumn{1}{|c|}{ Components } & \multicolumn{1}{c|}{ Values } \\
\hline 1. & Coefficient Correlation $(\mathrm{r})$ & 0,446 \\
\hline 2. & Significant Difference & Moderate \\
\hline 3. & $\mathrm{t}_{\text {count }}$ & 3,892 \\
\hline 4. & $\left(\mathrm{t}_{0,05(63-2)}\right.$ & 1,671 \\
\hline 5. & Significance & Real \\
\hline
\end{tabular}

The table presents that delegate function of a leader has significant correlation towards the success of Rural Agribusiness Development Program (PUAP). The r-value of 0.446 revealed as a moderate correlation. The t-test calculation appears of 3.892 that is higher than $t_{\text {count }}$ of 1.671 with degree of freedom of $5 \%$. This reveals that the correlation between the two variables is significantly different. It can be explained that the leader of Gapoktan delegated some duties to his and or her members who are believed to be responsible in training activities, meetings, assignments and the others [17]

\section{E. Control Functions and the Success of PUAP}

In order to answer the question of the correlation between the functions and the program, the authors conducted a Spearman Rank Coefficient Correlation Analysis. The results are shown in the following table:

TABLE V. THE CORRELATION BETWEEN CONTROL FUNCTIONS OF GAPOKTAN AND THE SUCCESS OF PUAP

\begin{tabular}{|l|l|l|}
\hline \multicolumn{1}{|c|}{ No } & \multicolumn{1}{|c|}{ Components } & \multicolumn{1}{c|}{ Values } \\
\hline 1. & Coefficient Correlation $(\mathrm{r})$ & 0,449 \\
\hline 2. & Significant Difference & Moderate \\
\hline 3. & $\mathrm{t}_{\text {count }}$ & 3.926 \\
\hline 4. & $\left(\mathrm{t}_{0,05(63-2)}\right.$ & 1,671 \\
\hline 5. & Significance & Real \\
\hline \multicolumn{2}{|c|}{ Source: Results of data analysis (2018) }
\end{tabular}

In line with the results of statistical calculation, the table shows a real significant correlation between the two variables; X5 (Control Functions) and Y (PUAP). Result of the tests then gained r-value of 0.449 . This demonstrates with 0.449 is classified as moderate. With degree of freedom of $5 \%$, $t$-test $(\mathrm{t}$ $t_{\text {count }}$ ) obtained from the calculation is 3.926 higher than $t_{0,05}$ of 1.671. This indicates that the correlation between the two variables is significantly different.

Control function means that a successful or effective leadership must be able to maintain effective regular activities in group members in order to reach the goals. The function can be realized in the form of guidance, advices, coordination and supervision.

Under his or her functions, the leader strives to prevent individual or group member mistakes to carry out the goal. Control is done by preventing members from thinking and doing something that tends to harm the common interest [18].

\section{F. Simultaneous Leadership Functions of Gapoktan and the Success of PUAP}

To discover the correlation between Simultaneous Leadership Functions of Gapoktan and the Success of PUAP, the author used Spearman Rank analysis. The outcome of statistical calculation on the two variables is in the following table: 
TABLE VI. THE CORRELATION BETWEEN SiMULTANEOUS LEADERSHIP FUNCTIONS OF GAPOKTAN AND THE SUCCESS OF PUAP

\begin{tabular}{|l|l|l|}
\hline No & \multicolumn{1}{|c|}{ Components } & \multicolumn{1}{c|}{ Values } \\
\hline 1. & Coefficient Correlation $(\mathrm{r})$ & 0,654 \\
\hline 2. & Significant Difference & Significant \\
\hline 3. & $\mathrm{t}_{\text {count }}$ & 6.754 \\
\hline 4. & $\left(\mathrm{t}_{0,05(63-2)}\right.$ & 1,671 \\
\hline 5. & Significance & Real \\
\hline \multicolumn{2}{|c|}{ Source: Results of data analysis (2018) }
\end{tabular}

According to the table above, result of $r$ value between the two variables based on Spearman Rank statistical too is 0.654 . The result is considered as significant. Meanwhile, to find out the significance of the relationship, t-test was conducted. With degree of freedom of $5 \%$, the $t_{\text {count }}$ gained was 6.754 which is higher than $t_{0,05}$ of 1,671 . This shows that Simultaneous Leadership Functions of Gapoktan and the Success of PUAP program is significantly different.

What in the table demonstrates that in variable dimension, Instructional Functions of a leader in Gapoktan has been able to provide some thorough roles for the members such as savings and loan activities in order to maintain PUAP capital funds. The leader required the head of the farmer group to announce the Definitive Plan for Groups (RDK) and the Definitive Plans for Group Needs (RDKK) of PUAP loan funds to their members. In order to participate in the savings and loan activities in terms of capital, the Gapoktan leader instructed the head of the farmer group to create a RDKK (Definitive Plans for Group Needs) which is carried out in every season. In consulting function dimension variable, the consultative form of the Gapoktan Chairperson, for example, explains the procedure for lending PUAP fund activities to prospective members of PUAP beneficiary funds, in the participatory function variable dimension, the Gapoktan chairperson has participated in the activities carried out by Gapoktan Tani Makmur, for example in making RDKK, RDK or routine meetings and meetings with members of farmer groups or with related agencies. In the variable dimensions the delegation function of the Gapoktan chairperson has delegated his duties to members for example giving authority / responsibility to members to complete the tasks assigned, the control function of the head of the farmer group for example in terms of controlling savings and loan activities strengthening PUAP fund capital by providing guidance to farmer group members, provide direction, coordinate and supervise PUAP funds, savings and loan activities.

The instructional function also means that the decisions made will be meaningless without the ability to realize into various instructions. Furthermore, the command will be unrelated without actions. Therefore, in line with the notion of leadership, the point is the ability of the leaders to encourage all members to carry out orders, which are sourced from decisions that have been determined [19]. In addition, the consulting function provides an opportunity for members to argue or give advice to the leaders to be listened to. Accordingly, a good listener is asked to be able to convince himself that it is always possible to obtain ideas, aspirations, constructive suggestions for the development of his own leadership [20]. In general, the delegation of authority can be done by giving different tasks or responsibilities to the group members [18]. The activity of controlling in an organization depends on the ability to foster the people who are involved with and manage to become the dream team. Guidance, direction, coordination and supervision are parts and elements of a good leader to prevent mistakes among each unit or individual in carrying out workload. Control is done by preventing members from thinking and doing something that tends to harm the common interest [20].

\section{CONCLUSION AND SUGGESTION}

Based on the findings and discussion, it is concluded that there is a significant relationship between leadership functions (instructional, consulting, participation, delegation, and controlling function) of the Farmer Groups Association (GAPOKTAN) partially with the level of success of the Rural Agribusiness Development Program (PUAP) in Mayung Village, Gunung Jati. The better the functions of a GAPOKTAN, the higher level of success of the PUAP program will be.

There is a real relationship between leadership functions (instructional, consulting, participation, delegation, and controlling function) simultaneously with the success of the Rural Agribusiness Development Program (PUAP) in Mayung Village, Gunung Jati. The rs $=0.654$ and a value of 6.754 have a strong level of relationship. The better the Gapoktan leadership function the higher level of success of the PUAP program will be.

Based on the analysis and discussion, the research suggests Gapoktan leadership functions need to be improved, particularly in the instructional, consulting, participation, delegation and controlling function. Training of trainers is one of recommendations for the chairman of Gapoktan Tani Makmur in Mayung Village Cirebon to carry out similar studies that are deeper and more extensive for the future of Group Farmers Associations in the district.

\section{REFERENCES}

[1] A. Faqih. 2016. Model Pemberdayaan Kelompok Tani Pesisir Pantai. Ed.1, Cet 1. Yogyakarta: Penerbit Dee Publish.

[2] A.H. Nasution and A. Barizi, Metode Statistik Untuk Penarikan Sampel. Jakarta: PT. Gramedia.

[3] S. Arikunto, Prosedur Penelitian Suatu Pendekatan Praktik. Cetakan Ke8. Yogyakarta: Rineka Cipta, 1998.

[4] F. Kasryno, Prospek Pembangunan Ekonomi Pedesaan Indonesia Jakarta: Yayasan Obor Indonesia, 2008.

[5] H. Haryono, Kepemimpinan Peran Serta dan Produktivitas. Bandung Bandar Maja, 2004

[6] IBSRAM, Evaluation for sustainable land management in the developing world, International Board for Soil Research \& Management. Bangkok, Thailand, 1991.

[7] Kementerian Pertanian, Pedoman Umum Pengembangan Usaha Agribisnis Perdesaan. Jakarta: Kementerian Pertanian, 2008.

[8] A. Lafond and L. Brown, "A guide to monitoring and evaluation of capacity-building interventions in the health sector in developing countries," MEASURE Evaluation Manual Series No. 7. Carolina Population Center, University of North Carolina at Chapel Hill, 2003. 
[9] C. Lusthaus, M.H. Adrien, and M. Perstinger, Capacity development: Definitions, issues, and implications for planning, monitoring, and evaluation. Montreal: Universalia, 1999.

[10] R. Mackay and D. Horton, "Capacity development in planning, monitoring, and evaluation: Results of an evaluation. Briefing Paper No. 51. The Hague: International Service for National Agricultural Research, 2002.

[11] D. Mulyadi and V. Rivai, Kepemimpinan dan Perilaku Organisasi. Jakarta: Rajawali Press, 2012.

[12] A. Qualman and J. Bolger, Capacity development: A holistic approach to sustainable development. Development Express No. 8. Canada: International Development Information Centre, 1996.

[13] D. Russ-Eft and H. Preskill, Evaluation in organizations. A systematic approach to enhancing learning, performance, and change. Boston, MA: Perseus Books, 2001.

[14] R.C. Sonnichesen, High impact internal evaluation. Thousand Oaks, CA: Sage, 2000
[15] E. Suharto, Membangun Masyarakat Memberdayakan Rakyat Kajian Strategis Pembangunan Kesejahteraan Sosial dan Pekerjaan Sosial. Bandung: PT Refika Aditama, 2010.

[16] W. Sunanjaya and N. Sumawa, Identifikasi dan Peluang Pengembangan Potensi Desa. Apresiasi Inovasi Teknologi Pertanian Mendukung PUAP 2009. Denpasar: Balai Pengkajian Teknologi Pertanian Bali, 2009.

[17] S. Taschereau, Evaluating the impact of training and institutional development programs: A collaborative approach. Washington DC: The International Bank for Reconstruction and Development - The World Bank, 1998 .

[18] N. Uphoff and C.M. Wijayaratna, "Demonstrated Benefits from Social Capital: The Productivity of Farmer Organizations in Gal Oya, Sri Lanka," World Development, vol. 28, no. 11, pp. 1875-1890, 2000.

[19] H.N. Utami, Keberdayaan, Kemajuan, dan Keberlanjutan Usaha Pengrajin: Kasus Kabupaten Sidoarjo dan Kabupaten Magetan Provinsi Jawa Timur[Disertasi]. Fakultas Ekologi Manusia, Institut Pertanian Bogor, 2006.

[20] C.H. Weiss, The interface between evaluation and public policy," Evaluation, vol. 5, no. 4, pp. 468-486, 1999. 